\title{
Prevalence of Colacium vesiculosum (Colaciales: Euglenophyceae) on planktonic crustaceans in a subtropical shallow lake of Argentina
}

\author{
Yolanda Zalocar, Santa Margarita Frutos, Sylvina Lorena Casco, Marina Elizabet Forastier \& \\ Silvina Vanesa Vallejos \\ Centro de Ecología Aplicada del Litoral (CONICET). C.C. 291, 3400-Corrientes (Argentina) Departamento de \\ Biología, Facultad de Ciencias Exactas y Naturales y Agrimensura (UNNE) Corrientes, Argentina; \\ zalocaryolanda492@gmail.com, margaritafrutos_587@yahoo.com.ar, sylvina.casco@gmail.com, \\ marinaforastier@hotmail.com, vallejossilvi24@hotmail.com
}

Received 12-X-2010. C Corrected 07-I-2011. Accepted 04-II-2011.

\begin{abstract}
Colacium vesiculosum (Euglenophyceae) is an epibiont common on planktonic microcrustaceans of continental waters. The interaction between epibionts and substrate organisms is not very well known, particularly in subtropical environments of South America. In the present work, we analyzed the prevalence, density, biomass and attachment sites of $C$. vesiculosum on planktonic microcrustaceans from Paiva Lake, a subtropical lake of Argentina. With the aim to evaluate whether epibionts affect the filtering rates of Notodiaptomus spiniger, the dominant planktonic crustacean, we carried out bioassays using phytoplankton $<53 \mu \mathrm{m}$. Crustaceans were sampled using a PVC tube $(1.2 \mathrm{~m}$ long and $10 \mathrm{~cm}$ in diameter), filtering $50 \mathrm{~L}$ of water through a $53 \mu \mathrm{m}$-mesh. Microcrustaceans were counted in Bogorov chambers under a stereoscopic microscope. The infested organisms were separated and observed with a photonic microscope to determine density and biovolume of epibionts, by analyzing their distribution on the exoskeleton. The prevalence of $C$. vesiculosum was higher in adult crustaceans than in their larvae and juveniles. The most infested group was that of calanoid copepods, related to their high density. The attachment sites on the exoskeleton were found to be the portions of the body which have a higher probability of encounter with epibionts during locomotion and feeding, i.e., antennae and thoracic legs in copepods, and thoracic legs and postabdomen in cladocerans. The similar values found in the filtering rate of infested and uninfested individuals of $N$. spiniger and the constant prevalence $(<40 \%)$ of epibiont algae, suggest that $C$. vesiculosum does not condition the life of planktonic crustaceans of Paiva Lake. Rev. Biol. Trop. 59 (3): 1295-1306. Epub 2011 September 01.
\end{abstract}

Key words: epibiont, Colacium vesiculosum, prevalence, bioassay, Notodiaptomus spiniger, filtering rate, shallow lake.

The exoskeleton of freshwater planktonic crustaceans is the attachment substrate preferred by Colacium (Dubovskaya et al. 2005). These phototrophic flagellates are an exception among Euglenophyceae because they are sessile during the vegetative phase. Only during the attached phase they form large multicellular dichotomic colonies via asexual reproduction. When these cells are released, they are temporarily part of the plankton until they find another zooplankton host (Al-Dhaheri \& Willey 1996). Therefore, during the free phase they may be consumed by their crustacean hosts. Nevertheless, both the crustacean and the epibiont are predated by planktivorous fishes (Willey et al. 1990, Dubovskaya et al. 2005).

Previous studies have discussed the negative effects of epibiont algae on crustacean hosts: their increasing sinking rate, the possible interference with their feeding rate and their diminished capacity to escape from predators (Kiorboe et al. 1985, Willey et al. 1990, Allen et al. 1993, Chiavelli et al. 1993, Threlked \& Willey 1993, Weissman et al. 1993, Willey 
\& Threlked 1993). Several researches have demonstrated that the level of epibiont infestation is independent of the nutrient concentration in the water (Willey et al. 1990, Chiavelli et al. 1993, Lagus \& Lindholm 2000, Dubovskaya et al. 2005). In temperate lakes, epibiont algae frequently co-exist with cyanobacterial blooms (Gaevskii et al. 2004, Dubovskaya et al. 2005).

The epibiont-host relationship could be considered as a mutualistic interaction, where a positive cost-benefit balance exists for both species (Barea-Arco et al. 2001, Gaevskii et al. 2004). There is evidence showing that the development rates of epibionts on the crustacean zooplankton is correlated to the substrate species, but that their mortality is caused mainly by low food quality and predation by planktivorous fishes (Dubosvskaya et al. 2005). Most of the research with epibiont algae has been carried out in temperate lakes of the Northern Hemisphere, but in tropical and subtropical lakes of South America these studies are scarce (López et al. 1998, RegaliSeleghim \& Godinho 2004, Zalocar de Domitrovic et al. 2008).

The aims of this study were: (1) to determine the density and biomass variation and prevalence of the epibiont Colacium vesiculosum on Cladocera and Copepoda and the relation with the main environmental variables in a subtropical shallow lake, (2) to evaluate the zooplankton hosts preferred by $C$. vesiculosum Ehrenberg and its specific attachment sites on the exoskeleton, (3) to analyze the effect of $C$. vesiculosum on the filtering rate of the calanoid copepod Notodiaptomus spiniger Brian.

\section{MATERIALS AND METHODS}

Study site: Zooplankton was sampled from Paiva Lake $\left(27^{\circ} 28^{\prime} 51^{\prime \prime}\right.$ S-58 $45^{\circ} 05^{\prime}$ " $\mathrm{W})$, in the Northwest of Corrientes province, Argentina, from May 2002 to May 2003. This shallow lake has an area of 70ha and a mean depth of $1.0 \mathrm{~m}$. Different aquatic and littoral macrophytes cover $60 \%$ of the lake area.
Sampling design: Three zooplankton samples were taken in limnetic area (without vegetation) with a trap tube sampler similar to that used by Paggi et al. (2001). Our sampler consists of a PVC tube $(1.2 \mathrm{~m}$ long; $10 \mathrm{~cm}$ in diameter) provided with a closing mechanism. Water (50L) was filtered by a $53 \mu \mathrm{m}$-mesh net and preserved in a sucrose $4 \%$ formalin solution. Subsurface (30-40cm depth) samples of phytoplankton were taken with a Van Dorn bottle and fixed with Lugol's acidified solution. Environmental variables such as water temperature $\left({ }^{\circ} \mathrm{C}\right)$, transparency (Secchi disk), $\mathrm{pH}$, conductivity (YSI 33 SCT conductometer) and dissolved oxygen (YSI 54 A oxygen meter) were determined in situ. Nutrient analyses (Nitrites+Nitrates, Ammonium and Orthophosphates) were performed by the staff of the Chemical Laboratory of the CECOAL, following APHA techniques (1995). Precipitations and solar radiation were recorded with a LICOR (LI-12005) data logger (Table 1).

Phytoplankton density was estimated by the Utermöhl method (1958) using an inverted microscope. Crustaceans were counted in Bogorov chambers using a stereoscopic microscope (Downing \& Rigler 1984).

Cladocera and Copepoda with epibionts were separated and observed with light microscopy (400X and $1000 \mathrm{X}$ magnification). To analyze the distribution of $C$. vesiculosum, different regions $(\mathrm{R})$ of the crustacean hosts were considered (Fig. 1). R I: corresponds to the first pair of antennae in copepods and to the second pair of cladocerans. R II: in copepods it includes the metasome (the head and the thorax with their respective appendages), whereas in cladocerans it involves the head and the anterior part of the carapace including the thoracic legs. R III: in copepods it corresponds to the urosome with caudal ramus, whereas in cladocerans it includes the posterior part of the carapace and the postabdomen.

Colacium may be present as single-celled or multicellular colonies. The analysis of each microcrustacean involved the quantification of colonies, cells in each colony (proportional to 
TABLE 1

Seasonal mean values $( \pm \mathrm{SD})$ of environmental variables and density of phytoplankton registered during study period

$\begin{array}{lccccc} & \text { Autumn } & \text { Winter } & \text { Spring } & \text { Summer } & \text { Autumn } \\ \text { Depth }(\mathrm{m}) & 1.23(0.5) & 1.07(0.11) & 0.98(0.3) & 0.65(0.12) & 1.14(0.31) \\ \text { Precipitations }(\mathrm{mm}) & 98(95) & 39(65) & 41(41) & 60(45) & 87(78) \\ \text { Temperature }\left({ }^{\circ} \mathrm{C}\right) & 19(1.1) & 18(2) & 22.4(2.8) & 27.2(0.7) & 19(1.9) \\ \text { Secchi depth }(\mathrm{cm}) & 114(13) & 101(16) & 82(20) & 58(9) & 104(14) \\ \text { Conductivity }(\mu \mathrm{S} / \mathrm{cm}) & 43(2.5) & 48(6) & 51(8.5) & 60(5) & 38(3) \\ \text { Dissolved oxygen }(\mathrm{mg} / \mathrm{L}) & 8.2(1.9) & 8.2(1.1) & 6.1(0.2) & 5.9(1.1) & 6.1(0.7) \\ \mathrm{pH} & 6.9(1.1) & 6.8(0.4) & 6.9(0.6) & 5.9(0.5) & 6.9(0.4) \\ \text { Radiation }\left(\mathrm{MJ} / \mathrm{m}^{2}\right) & 15.8(4.3) & 13.6(2.3) & 23.7(4.3) & 23.3(3.7) & \mathrm{wd} \\ \text { Ammonium }(\mu \mathrm{g} / \mathrm{L}) & 18.7(24) & 13.7(23.7) & 12.510 .6) & 15(7.1) & \mathrm{wd} \\ \text { Nitrites+Nitrates }(\mu \mathrm{g} / \mathrm{L}) & 17.5(15.5) & 16.7(20.2) & 65(92) & 7.5(3.5) & \mathrm{wd} \\ \text { Orthophosphates }(\mu \mathrm{g} / \mathrm{L}) & 129.5(4.9) & 152(51.9) & 202.5(48.8) & 365(70.7) & \mathrm{wd} \\ \text { Phytoplankton }(\mathrm{ind} / \mathrm{mL}) & 1839(11512) & 2849(1017) & 8302(4055) & 10656(2578) & \mathrm{wd}\end{array}$

wd: without data.

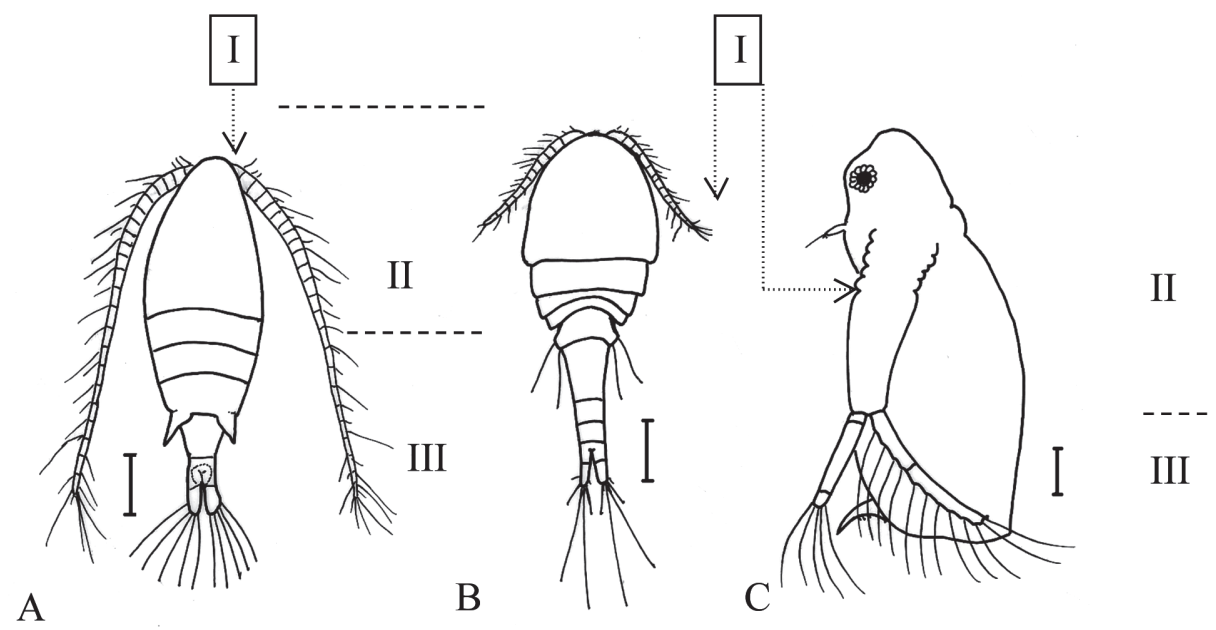

Fig. 1. Different body regions of calanoids, cyclopoids and cladocera (RI, RII, RIII) considered for the study of Colacium distribution. The scales correspond to $0.25 \mathrm{~mm}(\mathbf{A})$ and $0.10 \mathrm{~mm}(\mathbf{B}$ and $\mathbf{C})$.

the number of cellular divisions), and unicellular forms attached to the host.

The epibiont prevalence was estimated in each sample. This analysis was calculated as the ratio between the number of crustaceans recorded with Colacium and the total number of individuals examined x 100 (as \%). This ratio is useful to characterize the prevalence of overgrowth in a population (Gaevskii et al. 2004). The burden of overgrowth may be characterized by the average number of epibionts per individual for the sample of overgrown specimens, expressed in relative units -grade/ ind- or absolute units -cell/ind- (Gaevskii et 
al. 2004). In our study, we used the last units: cell density (cell/ind=cell/crustacean), and estimated density of colonies (colonies/crustacean) and biomass $\left(\mu \mathrm{m}^{3} /\right.$ crustacean). Each cell of Colacium was approximated to geometric forms to calculate biomass as biovolume (Rott 1981).

Biotic and abiotic variables were correlated using the Spearman Rank Order Correlations coefficient. To compare the results obtained in this study between infested and uninfested microcrustaceans, the Mann-Whitney (M-W) $U$ test was used. Kruskal-Wallis (K-W) test with Dunn's multiple comparison post-test was used to test for significant differences in $C$. vesiculosum density and biomass between calanoids, cyclopoids and cladocera (Steel \& Torrie 1988).

Bioassays: determination of the filtering rate in Notodiaptomus spiniger Brian: In order to evaluate whether $C$. vesiculosum affects the filtering rate of microcrustaceans, assays using $N$. spiniger (dominant calanoid copepod in zooplankton) were carried out on May 14-16, 17-19 and 29-31, 2002, under 4000luxes continuous light and mild shaking every $2 \mathrm{~h}$. Water temperature was maintained at $21 \pm 2^{\circ} \mathrm{C}$.

Transparent bottles $(600 \mathrm{~mL})$, filled with water and phytoplankton collected from the lake previously filtered through a $53 \mu \mathrm{m}$-mesh, were used for the assays.

The length of the assays and the number of copepods to be used in each bottle was based on the number of deaths observed during the first $96 \mathrm{~h}$. Thus, a preliminary assay was carried out in triplicate, with 10,20 and 30 adult copepods and observations every $2 \mathrm{~h}$. In all the cases, organisms had an infestation percentage between 50 and $75 \%$.

Preliminary assays with 10 calanoids showed a death rate below $5 \%$ after $24 \mathrm{~h}$. This value then increased to $20-50 \%$ after $72 \mathrm{~h}$ and to $55-80 \%$ at the end of the assay. On the other hand, in assays with 20 and 30 calanoids, the death rate oscillated between $60-80 \%$ after
$24 \mathrm{~h}$, and therefore the use of these quantities was discarded.

Four definitive assays of $48 \mathrm{~h}$ were carried out in triplicate. Ten copepods were used in each bottle: 1) five males +5 infested females, 2) five males +5 uninfested females, 3 ) ten infested fertilized females, 4) ten uninfested fertilized females. At the same time, bioassays using only phytoplankton $(<53 \mu \mathrm{m})$ were carried out.

Phytoplankton density was estimated at the beginning of all assays and every $2 \mathrm{~h}$. A subsample of $10 \mathrm{~mL}$ was fixed with Lugol's acidified solution and counted on an inverted microscope (Utermöhl 1958). The filtering rate (FR) was calculated using Gauld's equation (Downing \& Rigler 1984):

$$
\mathrm{FR}=\mathrm{V}\left(\ln \mathrm{C}_{0}-\ln \mathrm{C}_{1}\right) /(\mathrm{tN}),
$$

where $\mathrm{V}=$ volume of the bottle in $\mathrm{ml}, \mathrm{C}_{0=}$ initial phytoplankton concentration, $\mathrm{C}_{1}=$ final phytoplankton concentration. $\mathrm{N}=$ number of herbivores, $\mathrm{t}=$ time in hours. Results were expressed as $\mathrm{mL} / \mathrm{ind} / \mathrm{h}$. This equation assumes that phytoplankton cell number is reduced by a constant fraction per unit time.

A non-parametric analysis of variance (K-W test) with Dunn's multiple comparison post-test was used to test for significant differences in FR between bioassays.

\section{RESULTS}

Prevalence variation, density and biomass of Colacium vesiculosum: The density of plankton crustaceans showed an annual variation range between 32 and 460ind/L (Mean=121 \pm 98 ) and was characterized by the dominance of copepods (Calanoidea>Cyclopoidea) over cladocerans.

The prevalence of all crustaceans was low $(<40 \%)$ except in may 2003 (62\%; Fig. 2). The density of uninfested (U) was higher than infested (I) crustaceans (M-W $U$ test $=423.5$, $\mathrm{p}<0.001)$.

High density of crustaceans was accompanied of high density of Colacium vesiculosum 


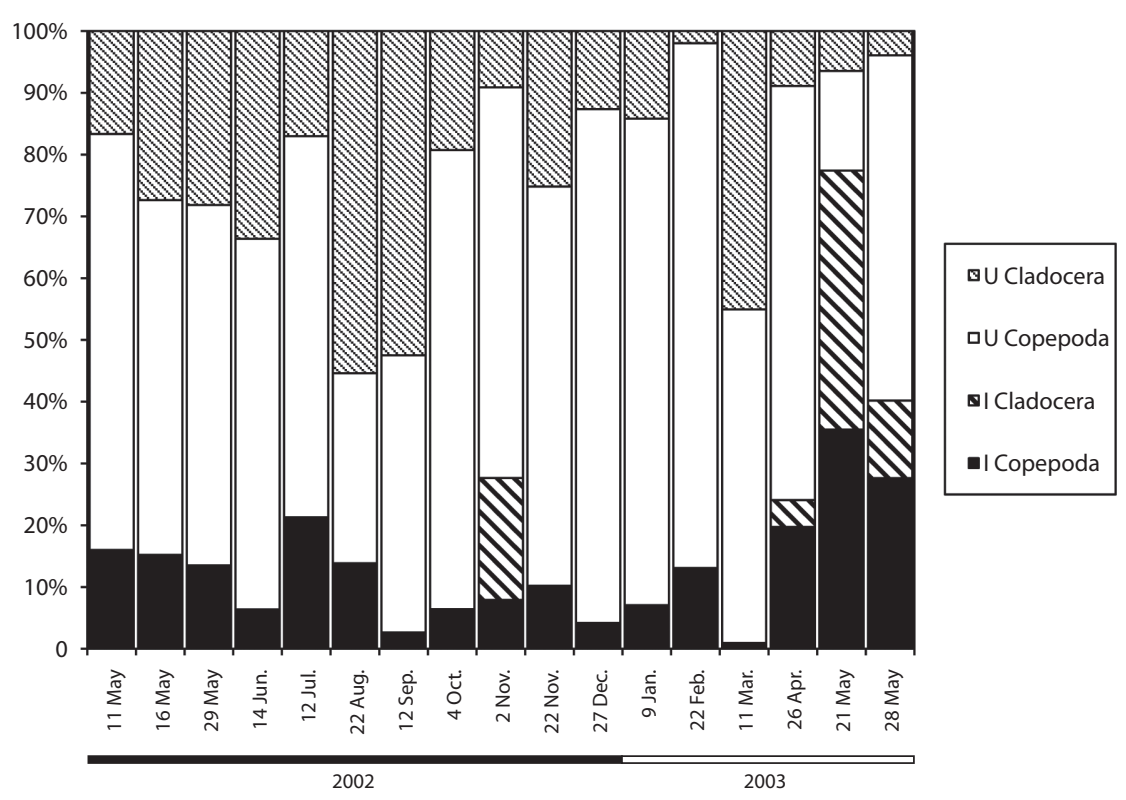

Fig. 2. Temporal variations of relative abundance of density in infested (I) and uninfested (U) Copepoda and Cladocera.

$\left.\left(\mathrm{r}_{\mathrm{s}}=0.679, \mathrm{p}<0.05\right), \mathrm{df}=32\right)$. C. vesiculosum exhibited mean density values between $168 \pm 137$ (winter/02) and 6.049 \pm 4.367 cell/crustacean (autumn/03), and biomass between $0.4 \times 10^{6} \pm 0.3 \times 10^{6}$ and $10.8 \times 10^{6} \pm 9.0 \times 10^{6} \mu \mathrm{m}^{3 /}$ crustacean, respectively. Comparison in density and biomass of $C$. vesiculosum between the three principal groups of microcrustaceans by $\mathrm{K}-\mathrm{W}$ and Dunn test showed highly significant prevalence in calanoid over cyclopoid and cladocera (Table 2).

C. vesiculosum had higher density and biomass in the Notodiaptomus spiniger Brian (calanoid dominant species in the lake) than

TABLE 2

Non-parametric analysis of variance (Kruskal-Wallis) and Dunn's multiple comparison post-test in density and biomass of Colacium vesiculosum between calanoids, cyclopoids and cladocerans

\begin{tabular}{|c|c|}
\hline \multicolumn{2}{|c|}{ Density of Colacium vesiculosum $(K W=21.279)$} \\
\hline Comparison & Dunn's Multiple Comparison test \\
\hline Calanoids vs. Cladocerans & $* * * \mathrm{p}<0.001$ \\
\hline Calanoids vs. Cyclopoids & $* * \mathrm{p}<0.01$ \\
\hline Cyclopoids vs. Cladocerans & ns $\mathrm{p}>0.05$ \\
\hline \multicolumn{2}{|c|}{ Biomass of Colacium vesiculosum $(K W=26.339)$} \\
\hline Comparison & Dunn's Multiple Comparison test \\
\hline Calanoids vs. Cladocerans & $* * * \mathrm{p}<0.001$ \\
\hline Calanoids vs. Cyclopoids & $* * * \mathrm{p}<0.001$ \\
\hline Cyclopoids vs. Cladocerans & ns $\mathrm{p}>0.05$ \\
\hline
\end{tabular}


in Thermocyclops minutus Lowndes (subdominant species in the lake). Algal colonization was higher in adult forms than in larval and juvenile forms (nauplii and copepodites), with a prevalence below $5 \%$. In cladocerans, infestation affected mainly Diaphanosoma birgei
Kořinek and was occasional in Bosminopsis sp. and Daphnia laevis Birge.

Calanoid copepods were infested during all the cycle studied (Fig. 3). The burden overgrowth was intensified in autumn and spring (Fig. 4A). Infestation of cyclopoids was highly
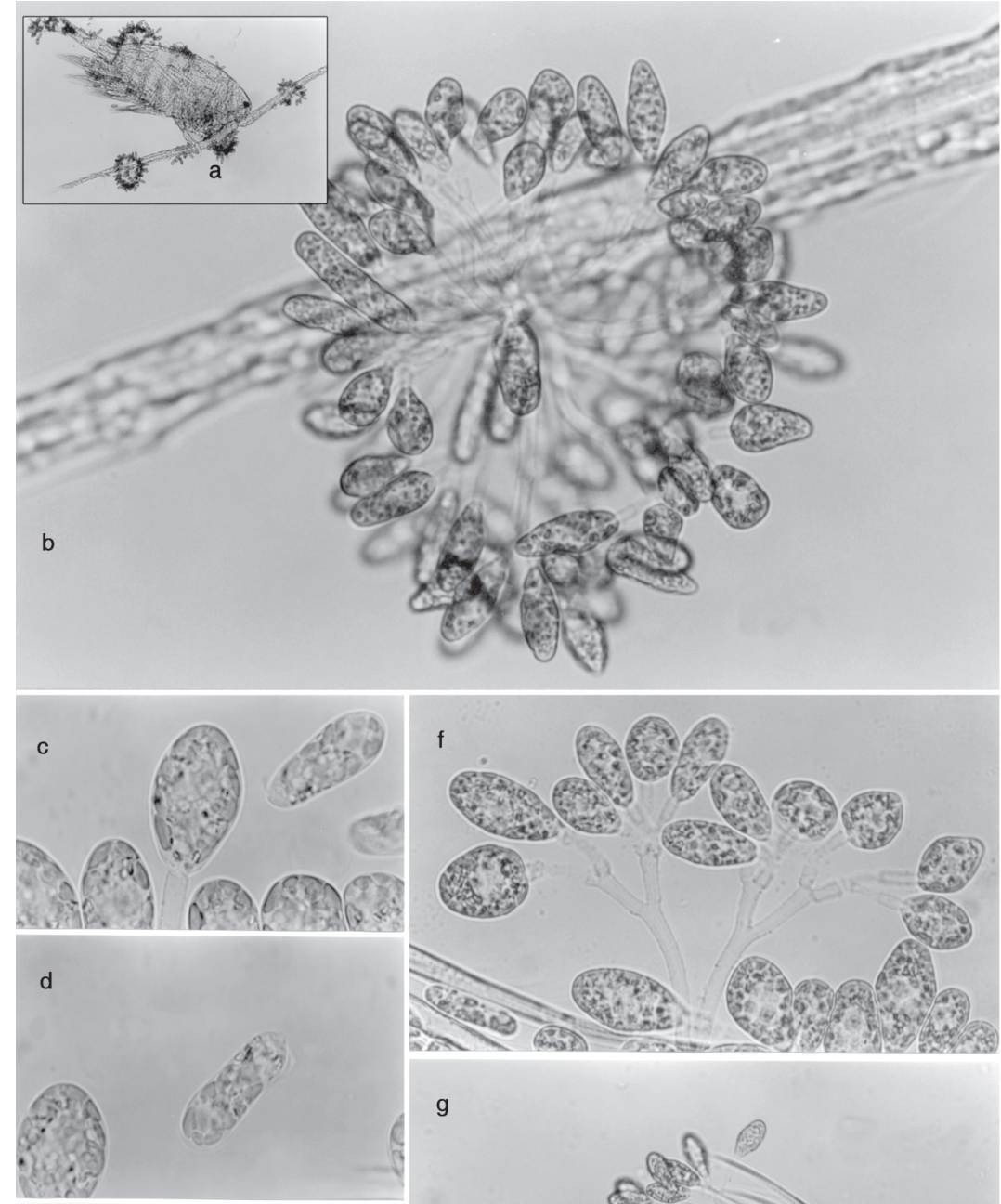

g
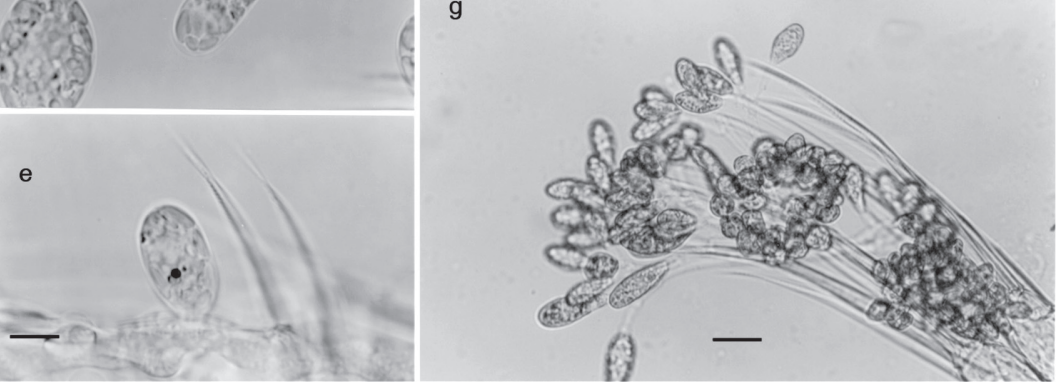

Fig. 3. (A) General aspect of Notodiaptomus spiniger infested by C. vesiculosum; (B) Colony of Colacium vesiculosum on the first pair of antennae; C-E: View of a zooid $(\mathbf{C})$ at the time of release from the colony (D) and moving (E) to fix on another host; (F) General view of a branched colony; (G) Group of cells colonizing the caudal ramus. The scale corresponds to $10 \mu \mathrm{m}$. 

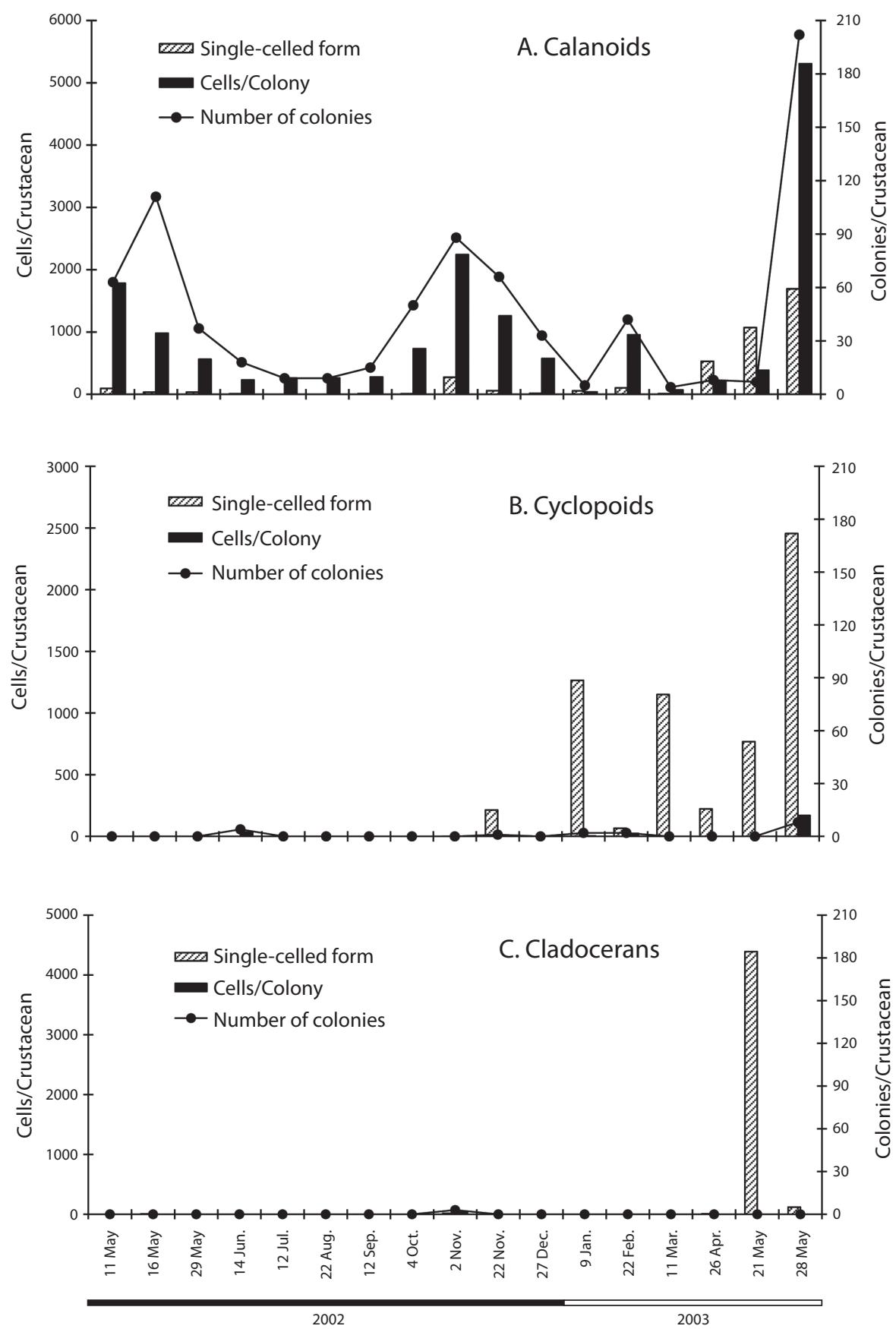

Fig. 4. (A) on Calanoids, (B) on Cyclopoids, (C) on Cladocerans. Density of epibionts (cell/crustaceans): Mean value of attached single-celled forms, number of colonies and cell number per colony of Colacium on Calanoids, Cyclopoids and Cladocerans. 
variable from November/02 to May/03 (Fig. 4B). Infestation of cladocerans was high only in May/03 (Fig. 4C).

High density of $C$. vesiculosum on the three crustaceans groups (Fig. 4) was punctually observed in autumn (May/03). Large colonies in adult calanoid copepods and greater density of single-celled forms were punctually noted in May/03. Variable density of this form was observed in all crustaceans groups. In cyclopoid copepods, this single-celled form was recorded from spring/02 to autumn/03 (Fig. 4B). Also, in Cladocera, this was the only form present in autumn/03 (Fig. 4C).

The environmental variables and phytoplankton density recorded in the lake are listed in Table 1. The total density of microcrustaceans $(\mathrm{I}+\mathrm{U})$ was correlated only with water conductivity $\left(\mathrm{r}_{\mathrm{s}}=0.577, \mathrm{p}<0.052, \mathrm{df}=32\right)$. The prevalence, however, showed no significant correlation with the abiotic and biotic variables listed in Table 1.

Zooplankton-host preference and their site-specific attachment on the exoskeleton: A high variability of prevalence was observed in calanoids (31-100\%) respect to cyclopoids $(0-60 \%)$ and cladocerans $(0-50 \%)$. The higher prevalence was related to density of copepods, principally calanoids $\left(\mathrm{r}_{\mathrm{s}}=0.651, \mathrm{p}<0.005\right.$, $\mathrm{df}=32)$ followed by cladocerans $\left(\mathrm{r}_{\mathrm{s}}=0.486\right.$, $\mathrm{p}<0.05, \mathrm{df}=32$ ).

The epibiont biomass (Fig. 5) had no uniform distribution on the exoskeletons of microcrustaceans. In calanoid copepods, $C$. vesiculosum was concentrated on the first pair of antennae (R I; 38-57\%) and then on the urosome (R III; 27-53\%). In the latter region, the genital segment was the preferred attachment site followed by the caudal branch. In cyclopoid copepods, the urosome was the preferred region (RIII) followed by the metasome (R II). In cladocerans, the preferred attachment sites were the thoracic legs (R II, Fig. 5).

Bioassays: determination of the filtering rate in Notodiaptomus spiniger: Bioassays carried out in the laboratory showed that the FR was higher in uninfested (Mean $=0.516 \mathrm{~mL} /$ $\mathrm{ind} / \mathrm{h}$ ) than in infested copepods of $N$. spiniger $(\mathrm{M}=0.063 \mathrm{~mL} / \mathrm{ind} / \mathrm{h})$. It is important to note that, among females, the FR was higher in infested females $(\mathrm{M}=0.687 \mathrm{~mL} / \mathrm{ind} / \mathrm{h})$ than in uninfested females $(\mathrm{M}=0.165 \mathrm{~mL} / \mathrm{ind} / \mathrm{h})$. Filtering rates did not differ significantly between

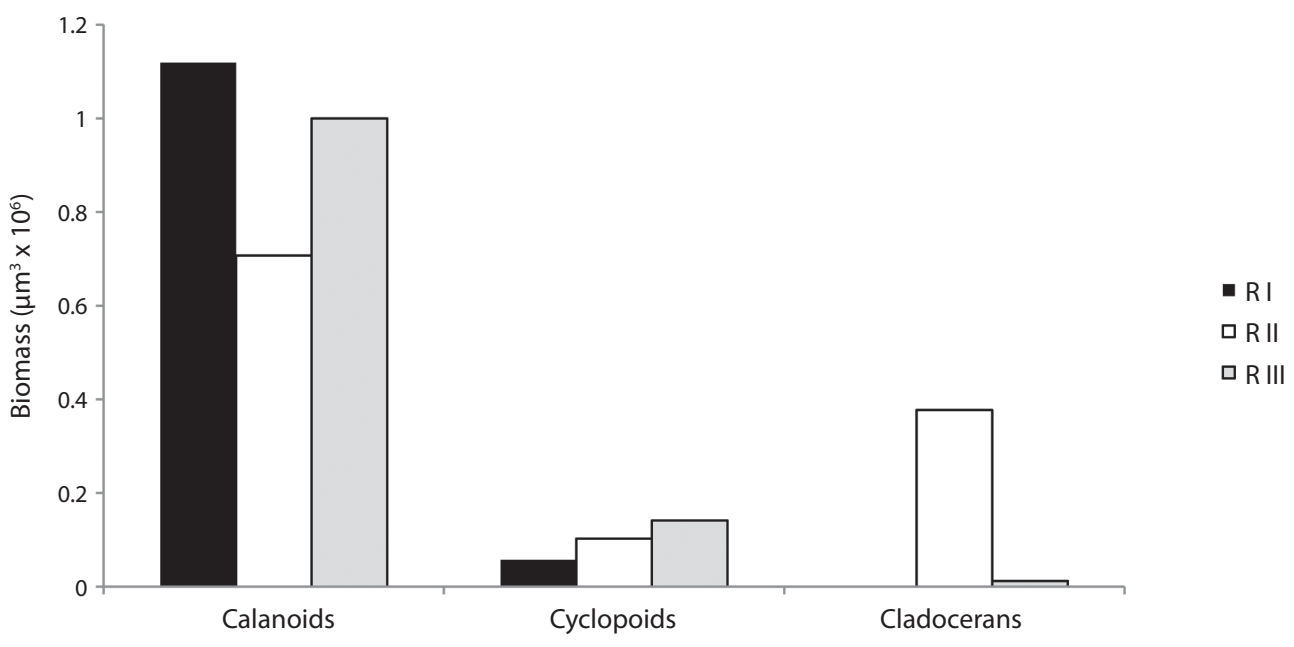

Fig. 5. Biomass and distribution of Colacium on the cuticular surface of copepods and cladocerans. The three body regions (RI, RII, RIII) correspond to those described in Fig. 1. 
TABLE 3

Mean values $( \pm$ S.D.) of the filtering rate of Notodiaptomus spiniger determined in the laboratory assays

\begin{tabular}{lcccc}
\multicolumn{1}{c}{ Filtering rate } & Infested $(n=90)$ & Uninfested $(n=90)$ & $U$ value & $p$ value \\
Males + unfertilized females & $0.062722( \pm 1.452936)$ & $0.516035( \pm 0.793974)$ & 27.0000 & 0.599511 \\
Fertilized females & $0.686791( \pm 0.873325)$ & $0.165279( \pm 0.588668)$ & 19.0000 & 0.172168
\end{tabular}

$U$ : Mann-Whitney $\mathrm{U}$ test; $n=$ number of copepods.

infested and uninfested individuals of N. spiniger (Table 3).

\section{DISCUSSION}

Notodiaptomus spiniger (Calanoid) and Thermocyclops minutus (Cyclopoid), the dominant microcrustaceans of Paiva Lake, are common in subtropical lakes of Argentina (Dussart $\&$ Frutos, 1985) and they are exclusively distributed in South America (Dussart \& Defaye, 1983). Also, Diaphanosoma birgei is a cladoceran recorded in rivers and lakes from the Neotropical region (Paggi 1998).

We assume that the algal density variation in open waters depended on the availability of water nutrients, although epibiont algae should obtain nutrients from their host substrate (Willey et al. 1990, Chiavelli et al. 1993, Lagus \& Lindholm 2000, Dubovskaya et al. 2005). However, the higher prevalence on calanoids compared to that of cyclopoids (adult and copepodite stage) was related to the larger carapace surface and the longer generation time of copepods. In this case, the probability of encounter between the two species $(C$. vesiculosum and Notodiaptomus spiniger), and host body size contributed to the increase in the abundance and biomass of epibiont algae, in contrast to that observed in Cladocera (Daphnia pulicaria and Korshikoviella) by PérezMartínez \& Barea-Arco (2000).

The increase in prevalence was caused by the increase in crustaceans host density (calano ids $>$ cyclopoids $>$ cladocerans) as several authors have noted (Chiavelli et al. 1993, Willey \& Threlkeld 1993, Barea-Arco et al. 2001, Dubovskaya et al. 2005). In the cladoceran host
(Diaphanosoma birgei), the low prevalence was associated with the combined effect of a smaller crustacean density, less exposure surface for algal attachment, and frequent molts that favored the dispersal of epibionts (Chiavelli et al. 1993, Barea-Arco et al. 2001, Dubovskaya et al. 2005). There are mutualistic interrelations between epibiont microalgae and cyclopoids (Gaevskii et al. 2004). Some of the ecological benefits produced by the epibiont algae attached are nutrient supply, mobility and optimum light conditions for photosynthesis (Møhlenberg \& Kaas 1990). Nevertheless, high loads of algal epibionts may provide additional food for the host and thus result in a net benefit (BareaArco et al. 2001). This might be a mutually beneficial relationship, since arborescent colonies of $C$. vesiculosum significantly increase the surface-volume relation to copepods, thus enhancing the buoyancy. In relation to the attachment preference, our results demonstrated that the specific region of the exoskeleton on the zooplankton host was variable in each microcrustacean species.

In calanoid copepods, biomass concentration on the first pair of antennae (R I) could be attributed to a higher probability of encounter between epibionts and calanoids, which are exclusively filtrators and, therefore, filter high volumes of water during locomotion and feeding. The relative proportion of epibionts on the genital segment (R III) could not be attributed to a probability of encounter. Indeed, it would be related to the fact that these areas are exposed to nutrients excreted by the animal during defecation (Lehman 1980). Gaiser \& Bachmann (1994) reported that epizoic diatoms would be more productive in this segment than 
in other regions of the exoskeleton, especially if the concentration of nutrients has been exhausted by the phytoplankton.

In cyclopoid copepods, as in calanoids, the presence of Colacium in the urosome ( $\mathrm{R}$ III) could be attributed to their exposure to excreted nutrients. Attachment to the metasome (R II), on the other hand, would probably be related to their feeding habits. Unlike calanoids, cyclopoids are not filtrators. They feed on vegetal and animal particles that they capture and take to their mouths using buccal pieces. Thus, the presence of $C$. vesiculosum in this region would be related to a higher probability of encounter with the algae they catch to feed, many of which adhere to their buccal pieces and thoracic legs (R II).

In cladocerans, filtrator forms as the ones described in this study (e.g. Diaphanosoma birgei) move their thoracic legs and generate a continuous flow of water between the valves, keeping suspended particles in their filtration seta. These particles go through the ventral channel towards the buccal region before being ingested. Non-ingestible particles are expelled outside by postabdominal energetic movements. Then, the probability of encounter would be enhanced in relation to the volume of water filtered, thus explaining the presence of small algae adhered to the thoracic legs (R II) and the postabdomen (R III).

The number of colonies and attached single-celled forms represent the colonization and reproduction events (Al-Dhaheri \& Willey 1996). During this study, the colonial and solitary forms appear together with different prevalence of both forms.

In our bioassays, the FR of Notodiaptomus spiniger was not affected by $C$. vesiculosum infestation. These results are not comparable with those of other authors, who studied the filtering rate with a different method (gut fluorescence) and with species from temperate or saline waters. For example, the filtering rate during the night varied between $0.3 \mathrm{ml} /$ copepod/h just after dusk to $0.8 \mathrm{ml} /$ copepod $/ \mathrm{h}$ just before dawn (Tsuda \& Nemoto 1988). Also, an increase according to the body weight would cause an exponential increase although this relation is better related to the filtering area (Lampert 1987). The environmental variables such as the temperature, light and other factors such as $\mathrm{pH}$ and oxygen concentration increase or decrease the filtering rate of Daphnia species (Lampert 1987). The filtering rate increases at slightly higher or lower $\mathrm{pH}$ values before they drop to the extremes. Some researches on the filtering rate by different species of Daphnia confirm that the maximum filtering rate varies with several environmental factors and with animal size (Lampert 1987). The minimum filtering rate in Daphnia pulicaria on Staurastrum has been found to be $0.1 \mathrm{ml} / \mathrm{ind} / \mathrm{h}$ and the maximum filtering rate in D. magna on Chlamydomonas $4.2 \mathrm{ml} / \mathrm{ind} / \mathrm{h}$ (Lampert 1987). Simocephalus vetulus showed a mean filtering rate higher on Chlorella vulgaris $8.96 \mathrm{ml} / \mathrm{ind} / \mathrm{h}$ than on Selenastrum capricornutum $2.02 \mathrm{ml} /$ ind/h (Brito et al. 2006).

In the shallow lake studied in this work, total crustacean density was correlated with water conductivity, whereas infested crustaceans density was correlated with dissolved oxygen concentrations. The epibiont algae probably contributed with the dissolved oxygen required by copepods. The photosynthesis of Colacium can widely satisfy the oxygen requirements of cyclopoids in the photic zone or in a moderate degree in the dysphotic zone (Gaevskii et al. 2004). In an experimental study, Willey et al. (1990) noted that the alternative infestation of $C$. vesiculosum on calanoid and cyclopoid copepods was related to the presence and absence of nutrients added to the water. In our study, the prevalence and nutrient concentration showed no significant correlation.

Our research showed that: (1) the crustacean hosts preferred by epibiont algae were calanoid copepods $>$ cyclopoids copepods $>$ cladocerans, related to their abundance in the lake. The high prevalence in adult calanoid copepods was associated with their high density; (2) the preferred attachment sites of the exoskeleton were those portions of the body that have more probability of encounter with epibionts during locomotion and feeding, such as the antennae 
and thoracic legs in copepods, and the thoracic legs and postabdomen in cladocerans; (3) in experimental conditions the epibiont algae did not affect the filtration rate of the calanoid copepod Notodiaptomus spiniger.

In the lake studied, the constant prevalence of C. vesiculosum on crustaceans and their low incidence on the filtering rates of $N$. spiniger, the dominant species of zooplankton, would indicate that epibionts do not play a key role in the regulation of planktonic crustacean populations. The ecological significance of these epibionts is still unclear. In fact, it is necessary to extend the studies in the microcosmos bioassay to know more on the true interaction between crustaceans and epibiont algae.

\section{ACKNOWLEDGMENTS}

We thank Visitación Conforti for their valuable suggestions and the revision of the manuscript. In addition, we thank CECOAL laboratory staff for the nutrient analysis, Luis Benetti, Casimiro Roberto and Miguel Solari, for their assistance in field sampling, and the anonymous reviewers, who contributed to improving the quality of this manuscript.

\section{RESUMEN}

Colacium vesiculosum Ehrenberg (Euglenophyceae) es un epibionte común en microcrustáceos del plancton de aguas continentales. La interacción epibiontes y organismo substrato es poco conocida, particularmente en ambientes subtropicales de América del Sur. Se analiza la prevalencia, densidad, biomasa y sitios de adhesión de C. vesiculosum en microcrustáceos planctónicos de un lago subtropical de Argentina. Con el fin de evaluar si los epibiontes afectan la tasa de filtración de Notodiaptomus spiniger Brian, crustáceo dominante del zooplancton, se realizaron bioensayos utilizando el fitoplancton $<53 \mu \mathrm{m}$. Los crustáceos fueron muestreados con un tubo de PVC (1m de largo, $10 \mathrm{~cm}$ de diámetro) filtrándose $50 \mathrm{~L}$ de agua a través de una red de $53 \mu \mathrm{m}$ de abertura de malla. El recuento de los microcrustáceos se realizó en cámaras de Bogorov bajo microscopio estereoscópico. Los organismos infectados fueron separados y observados al microscopio fotónico para determinaciones de densidad y biovolumen de los epibiontes, y su distribución en el exoesqueleto. La prevalencia de $C$. vesiculosum fue mayor en crustáceos adultos que en estadíos larvales y juveniles. El grupo más infestado fue el de los copépodos calanoideos en relación con su alta densidad. Los sitios de adhesión sobre el exoesqueleto fueron las regiones del cuerpo que durante la locomoción y alimentación tienen mayor probabilidad de encuentro con los epibiontes: antenas y patas toráxicas en copépodos, patas toráxicas y postabdomen en cladóceros. Valores similares en la tasa de filtración entre individuos infestados y no infestados de $N$. spiniger y la constante prevalencia $(<40 \%)$ del alga epibionte sugieren que $C$. vesiculosum no condicionaría la vida de los microcrustáceos planctónicos del lago Paiva.

Palabras clave: epibionte, Colacium vesiculosum, prevalencia, bioensayo, Notodiaptomus spiniger, tasa de filtración, lago somero.

\section{REFERENCES}

Al-Dhaheri, R.S. \& R.L. Willey. 1996. Colonization and reproduction of the epibiotic flagellate Colacium vesiculosum (Euglenophyceae) on Daphnia pulex. J. Phycol. 32: 770-774.

Allen, Y.C., B.T. De Stasio \& C.W. Ramcharan. 1993. Individual and population level consequences of an algal epibiont on Daphnia. Limnol. Oceanogr. 38: 592-601.

APHA (American Public Health Association). 1995. Standard methods for the examination of water and wastewater. APHA, AWWA and WPCF, Washington, D.C., U.S.A.

Barea-Arco, J., C. Pérez-Martínez \& R. Morales-Baquero. 2001. Evidence of a mutualistic relationship between an algal epibiont and its host, Daphnia pulicaria. Limnol. Oceanogr. 46: 871-881.

Brito, D., N. Milani \& G. Pereira. 2006. Tasa de filtración e ingestión de Simocephalus vetulus (Müller, 1776) (Crustacea: Cladocera) alimentado con Selenastrum capricornutum Printz, 1914 y Chlorella vulgaris Beijerinck, 1890. INCI 31: 753-757.

Chiavelli, D.A., E.L. Mills \& S.T. Threlkeld. 1993. Host preference, seasonality, and interactions of zooplankton epibionts. Limnol. Oceanogr. 38: 574-583.

Downing, J.A. \& F.H. Rigler. 1984. A manual on methods for the assessment of secondary productivity in freshwaters. Blackwell, Oxford, England.

Dubovskaya, O.P., E.P. Klimova, V.I. Kolmakov, N.A. Gaevsky \& E.A. Ivanova. 2005. Seasonal dynamic of phototrophic epibionts on crustaceans zooplankton in a eutrophic reservoir with cyanobacterial bloom. Aquat. Ecol. 39: 167-180. 
Dussart, B.H. \& D. Defaye. 1983. Répertoire mondial des crustacés copépodes des eaux intérieures I. Calanoïdes. Editions du Centre National de la Recherche Scientifique, París, France.

Dussart, B.H. \& S.M. Frutos. 1985. Sur quelques copépodes d'Argentine. Rev. Hydrobiol. Trop. 18: 305-314.

Gaevskii, A.N., V.I. Kolmakov, O.P. Dubovskaya \& E.P. Klimona. 2004. Interrelations of epibiontic microalgae and crustacean zooplankton under conditions of a blooming eutrophic water body. Russ. J. Ecol. 35: $35-41$.

Gaiser, E.E. \& R.W. Bachmann. 1994. Seasonality, substrate preference and attachment sites of epizoic diatoms on cladoceran zooplankton. J. Plankton Res. 16: 53-68.

Kiorboe, T., F. Mohlenberg \& H.U. Riisgard. 1985. In situ feeding rates of planktonic copepods a comparison of four methods. J. Exp. Mar. Biol. Ecol. 88: 67-81.

Lagus, A. \& T. Lindholm. 2000. Occurrence of the euglenoid epibiont, Colacium sp. on the rotifer Keratella cochlearis Gosse in coastal inlets in Aland, SW Finland. Arch. Hydrobiol. 149: 489-500.

Lampert, W. 1987. Feeding and nutrition in Daphnia, p. 143192. In R.H. Peters \& R. de Bernardi (eds.). Daphnia. Mem. Ist. Ital. Idrobiol., Verbania Pallanza, Italia.

Lehman, J.T. 1980. Release and cycling of nutrients between planktonic algae and herbivores. Limnol. Oceanogr. 25: 620-632.

López, C., E. Ochoa, R. Páez \& S. Theis. 1998. Epizoans on a tropical freshwater crustacean assemblage. Mar. Freshwater Res. 49: 271-276.

Møhlenberg, F. \& H. Kaas. 1990. Colacium vesiculosum Ehrenberg (Euglenophyceae), infestation of planktonic copepods in the western Baltic. Ophelia 31: $125-132$.

Paggi, J.C. 1998. Cladocera (Anomopoda y Ctenopoda), p. 507-518. In J.J. Marrone \& S. Coscarón (Dir.). Biodiversidad de artrópodos Argentinos, SUR, La Plata, Argentina.

Paggi, J.C., R.O. Mendoza, C.J. Debonis \& S.B. José de Paggi. 2001. A simple and inexpensive trap-tube sampler for zooplankton collection in shallow waters. Hydrobiologia 464: 45-49.

Pérez Martínez, C. \& J. Barea Arco. 2000. Relación entre el tamaño del hospedador y la intensidad de infección de un alga epibionte. Limnetica 19: 193-198.

Regali-Seleghim, M.H. \& M.J.L. Godinho. 2004. Peritrich epibiont protozoans in the zooplankton of a subtropical shallow aquatic ecosystem (Monjolinho Reservoir, São Carlos, Brazil). J. Plankton Res. 26: 501-508.

Rott, E. 1981. Some results from phytoplankton counting intercalibrations. Schweiz Z. Hidrol. 43: 34-61.

Steel, G.D. \& J.H. Torrie. 1988. Bioestadística: principios y procedimientos. McGraw-Hill, México, D.F., México.

Threlkeld, S.T. \& R.L. Willey. 1993. Colonization, interaction, and organization of cladoceran epibiont communities. Limnol. Oceanogr. 38: 584-591.

Tsuda, A. \& T. Nemoto. 1988. Feeding of copepods on natural suspended particles in Tokyo bay. J. Oceanog. Soc. Japan 44: 217-227.

Utermöhl, H. 1958. Zur vervollkommnung der quantitativen phytoplankton-methodik. Mitt._Int. Ver. Limnol. 9: $1-38$

Weissman, P., D.J. Lonsdale \& J. Yen. 1993. The effect of peritrich ciliates on the production of Acartia hundsonica in Long Island Sound. Limnol. Oceanogr. 38: 613-622.

Willey, R.L., P.A. Cantrell \& S.T. Threlkeld. 1990. Epibiotic euglenoid flagellates increase the susceptibility of some zooplankton to fish predation. Limnol. Oceanogr. 35: 952-959.

Willey, R.L. \& S.T. Threlkeld. 1993. Organization of crustacean epizoan communities in a chain of subalpine ponds. Limnol. Oceanogr. 38: 623-627.

Zalocar de Domitrovic, Y., M.E. Forastier, S.L. Casco \& V. Conforti. 2008. Epibiont algae on planktic microcrustaceans from a subtropical shallow lake (Argentina). Algol. Stud. 127: 29-38. 